\title{
Shearing Systems for Fraser Fir (Abies fraseri) Christmas Trees
}

\author{
Eric Hinesley ${ }^{1, *}$, Buddy Deal ${ }^{2}$ and Earl Deal ${ }^{2}$ \\ 1 Professor Emeritus, Department of Horticultural Science, North Carolina State University, Box 7609, Raleigh, \\ NC 27695, USA \\ 2 Smokey Holler Tree Farm, LLC, 3452 Meadowfork Road, Laurel Springs, NC 28644, USA; \\ info@smokeyhollertreefarm.com (B.D.); smokeyholler@skybest.com (E.D.) \\ * Correspondence: eric_hinesley@ncsu.edu; Tel.: +1-919-539-2707
}

Received: 8 April 2018; Accepted: 3 May 2018; Published: 4 May 2018

check for updates

\begin{abstract}
Plantation-grown Fraser fir (Abies fraseri (Pursh) Poir.) Christmas trees were subjected to nine shearing regimes over nine years in a plantation in western North Carolina (USA). Treatments differed in the year of onset as well as the length of the residual leader $(25$ to $46 \mathrm{~cm})$. Long leaders ( 36 to $46 \mathrm{~cm}$ ) yielded trees that were taller than trees sheared with short leaders ( 25 to $30 \mathrm{~cm})$, but the gain in height was offset by a lower average U.S. Department of Agriculture grade. Late in the rotation, trees sheared with 36-46-cm leaders were 17-34\% heavier than those with 25-30-cm leaders. Average wholesale price of trees sheared with long leaders was $57 \%$ greater than that of trees sheared with short leaders. Assuming good bud density on leaders and branches, and considering other factors as well, the optimum leader length for Fraser fir Christmas trees in western North Carolina appears to be 30 to $41 \mathrm{~cm}$ (12 to 16 inches). Depending on site quality and variation in bud density and vigor among individual trees, leader length can be reduced, if necessary, to increase crown density.
\end{abstract}

Keywords: Abies fraseri; Christmas tree; tree growth; USDA grade; leader length; rotation; tree weight; biomass; shearing systems; bud density; market value

\section{Introduction}

Fraser fir is one of the most important Christmas tree species in the United States. Standard cultural practices include one annual shearing to increase crown density, usually in mid- to late-summer. Fifty years ago, non-sheared Fraser fir frequently was harvested from wild stands on isolated mountain tops in western North Carolina, eastern Tennessee, and southwestern Virginia. Trees had a natural appearance, distinct branch whorls, and low crown density. Later, production shifted to plantations well below the elevation of natural stands, and annual shearing (shaping) was adopted. With passing time, tree density progressively increased, resulting in trees that were quite dense and heavy compared to non-sheared trees.

Although there is a wide window of time to shear true firs during the year, the ideal time is soon after cessation of shoot elongation in mid-summer (July and August) [1-5]. Shearing increases crown density of Fraser fir, but at the same time, also reduces potential growth, compared to non-sheared trees, by $40-55 \%$ depending on timing [4].

In the United States, the primary determinant of Christmas tree value is height, followed by crown density [6]. If trees are sheared with longer residual leaders, they potentially reach commercial height quicker and/or grow to a taller height class in a given number of years. This presumably would yield a tree with a more natural appearance, and might provide other advantages as well-e.g., less weight per tree, more trees per truck-but the effect on tree quality is unknown. The objective of this experiment 
was to determine the effect of residual leader length on tree growth, quality, and market value for plantation-grown Fraser fir Christmas trees.

\section{Methods and Materials}

\subsection{Field Site}

In 2001, a replicated field experiment was initiated in a plantation of Fraser fir near Laurel Springs, North Carolina, USA (Lat. 36.45379 N, Long. 81.25248 W), elevation 1020 m (3350 feet) above sea level. Tree height was 1 to $1.3 \mathrm{~m}$ ( 3 to 5 feet). The area bounded by the experiment was 30 rows $\times 23$ columns $(0.16 \mathrm{ha})$, and tree spacing was $1.5 \times 1.5 \mathrm{~m}$ within and between rows. Trees represented the fourth consecutive rotation of Fraser fir on that site.

The seed source of these plants was Roan Mountain, located on the North Carolina/Tennessee border in Avery County, NC, USA (Lat. $36^{\circ} 5^{\prime} 35^{\prime \prime}$ N, Long. $82^{\circ} 8^{\prime} 45^{\prime \prime}$ W). Smokey Holler Tree Farm acquired three-year-old seedlings from a forest tree nursery in Pennsylvania (USA), and grew them two more years outdoors to produce $3+2$ transplants. Trees had been in the field three years when the experiment was installed.

The soil series was a Tusquitee loam, 10-15\% slopes (Fine-loamy, isotic, mesic Humic Dystrudepts) [7]. The site is in U.S. Department of Agriculture 2012 Plant Hardiness Zone 6b, indicating an average annual extreme minimum temperature between $-23^{\circ} \mathrm{C}$ and $-15^{\circ} \mathrm{C}$ [8].

\subsection{Experimental Design}

The experimental design was completely random with nine shearing treatments (Table 1) and 60 replications (single-tree plots). Shearing regimes were randomly assigned to trees that were initially selected as suitable for inclusion in the experiment. Any plant that was too small, too large, or unhealthy in appearance was excluded.

Table 1. Leader lengths used in nine shearing regimes in Fraser fir Christmas trees.

\begin{tabular}{|c|c|c|c|c|c|c|c|c|c|c|}
\hline \multirow{3}{*}{$\begin{array}{c}\text { Shearing } \\
\text { Tmt }\end{array}$} & \multirow{3}{*}{$\begin{array}{l}\text { Height When } \\
\text { Shearing Began } \\
(\mathrm{m})^{1}\end{array}$} & \multicolumn{9}{|c|}{ Sheared Leader Length, by Year } \\
\hline & & 2001 & 2002 & 2003 & 2004 & 2005 & 2006 & 2007 & 2008 & 2009 \\
\hline & & \multicolumn{9}{|c|}{$(\mathrm{cm})^{2}$} \\
\hline 1 & 0.91 & 36 & 30 & 25 & 25 & 25 & 25 & 25 & 25 & 25 \\
\hline 2 & 0.91 & 30 & 30 & 30 & 30 & 30 & 30 & 30 & 30 & 30 \\
\hline 3 & 0.91 & 36 & 36 & 36 & 36 & 36 & 36 & 36 & 36 & 36 \\
\hline 4 & 0.91 & 41 & 41 & 41 & 41 & 41 & 41 & 41 & 36 & 36 \\
\hline 5 & 1.52 & - & 30 & 30 & 30 & 30 & 30 & 30 & 30 & 30 \\
\hline 6 & 1.52 & - & 36 & 36 & 36 & 36 & 36 & 36 & 36 & 36 \\
\hline 7 & 1.52 & - & 41 & 41 & 41 & 41 & 41 & 41 & 36 & 36 \\
\hline 8 & 0.91 & 46 & 41 & 36 & 30 & 30 & 30 & 30 & 30 & 30 \\
\hline 9 & 1.52 & - & 46 & 46 & 46 & 46 & 46 & 41 & 41 & 41 \\
\hline
\end{tabular}

${ }^{1}$ Trees were grown to a height $\geq 4 \mathrm{~m}$. Leader pruning began in some treatments when the terminal bud cluster reached a height of $0.9 \mathrm{~m}$; other treatments began at $1.5 \mathrm{~m}$ based on the assumption that delaying leader pruning might shorten the time to reach a specified commercial height. ${ }^{2} 1 \mathrm{~m}=3.28$ feet; $2.54 \mathrm{~cm}=1$ inch.

\subsection{Shearing Treatments}

Nine shearing regimes differed in time of onset as well as the length of the residual leader after each annual shearing (Table 1). Initially, there was no set date to terminate the experiment, but the intent was to grow some trees to a height $\geq 4 \mathrm{~m}$. Some treatments began when the terminal bud cluster reached a height of $0.9 \mathrm{~m}$. In other treatments, leader pruning began after the terminal bud cluster reached $1.5 \mathrm{~m}$. This difference ( 0.9 vs. $1.5 \mathrm{~m})$ was based on the assumption that delaying leader pruning might shorten the time for a tree to reach a specified height. In the first year of the experiment, some trees assigned to Treatments 5, 6, 7, and 9 were not tall enough to be leader pruned, but the 
terminal bud cluster was removed from each large lateral branch in the upper two whorls to help maintain narrow crown taper. Trees taller than $1.5 \mathrm{~m}$ were leader pruned to the prescribed length. Trees assigned to Treatments 1, 2, 3, 4, and 8 were leader pruned to $0.9 \mathrm{~m}$ in height the first year, and the large laterals in the upper whorls were tipped to control taper.

The range in leader lengths among shearing regimes was $25-46 \mathrm{~cm}$ (10-18 inches). Traditional shearing uses a leader length of about $30 \mathrm{~cm}$ (12 inches). Trees were sheared (leaders as well as sides) once annually in July or August. Side shearing was done with knives until trees grew beyond reach; then, extended pole pruners were used for trees up to 3 to $3.5 \mathrm{~m}$ in height. Above that height, workers used step ladders when cutting leaders and the top branch whorls. Crown taper was maintained at $25-30 \%$ to prevent excessive crowding as trees increased in size.

\subsection{Measurement of Tree Height, USDA Grade, and Market Value}

Beginning in 2005, trees were measured annually after shearing in late summer (July or August). Tree height was taken as the mid-point of the $0.3-\mathrm{m}$ (1-foot) commercial height class. For example, if a sheared leader was between $2.13 \mathrm{~m}$ and $2.44 \mathrm{~m}$ (7 to 8 feet), the commercial height class of that tree was recorded as $2.28 \mathrm{~m}$.

Trees were graded according to U.S. Department of Agriculture standards [9], and assigned numeric values as follows: ' 1 ' $=$ Premium or No. 1 , and ' 2 ' $=$ No. 2 . Two of 528 trees were classified as 'cull', and assigned a value of ' 2 '. A second option would have been to delete the two trees from the analysis. In either case, the cull trees likely had negligible effect on the analysis and interpretation. Wholesale price of each tree (\$ US) was based on the pricing system for Smokey Holler Tree Farm, which did not change materially during the experiment.

Harvesting began in November 2005, and continued through November 2009. There was no systematic method for harvesting. Each year, the decision to leave a tree was based on a subjective evaluation of two questions. First, "Would the quality of a tree be negatively impacted by leaving it an additional year?" Second, "Would leaving the tree an additional year negatively affect the quality of one or more neighboring trees?" As stand density decreased over time, there was more flexibility in deciding whether to leave a tree an additional year.

\subsection{Measurement of Tree Fresh Weight}

Fresh weight was recorded for 185 trees harvested in 2008 and 2009. Soon after cutting and baling, fresh weight was measured by suspending each tree beneath a dial scale attached to a frame mounted on the bucket of a tractor.

\subsection{Data Analysis}

The data for tree height, USDA grade and market value $(n=528$ trees) included all experimental trees harvested in 2005, 2006, 2007, and 2008 plus all experimental trees still present on the site in August 2009. In this scenario, the trees remaining on the site in 2009 were measured as if they were to be harvested during November and December that year.

A second analysis evaluated treatment effects on tree fresh weight for 185 trees harvested in 2008 and 2009. The identification of several trees was lost during harvesting and weighing in 2008, so the number of trees harvested (Table 2) was slightly more than the number weighed (Table 3). Similarly, the number of trees weighed in 2009 was a subset of all the trees on the site at the end of the 2009 growing season. 
Table 2. Height, USDA grade, and market value of Fraser fir Christmas trees sheared with various leader lengths.

\begin{tabular}{|c|c|c|c|c|}
\hline Year or Treatment & No. of Trees ${ }^{1}$ & Height (m) & Tree Grade $^{2}$ & Market Value (\$ US) \\
\hline \multicolumn{5}{|c|}{ Year } \\
\hline 2005 & 21 & $2.3 \mathrm{e}^{3}$ & $55 \mathrm{~b}$ & $36 \mathrm{~b}$ \\
\hline 2006 & 169 & $2.9 \mathrm{~d}$ & $60 \mathrm{~b}$ & $56 \mathrm{~b}$ \\
\hline 2007 & 69 & $3.1 \mathrm{c}$ & $58 \mathrm{~b}$ & $66 \mathrm{~b}$ \\
\hline 2008 & 111 & $3.6 \mathrm{~b}$ & $76 \mathrm{ab}$ & $149 \mathrm{a}$ \\
\hline 2009 & 157 & $3.9 \mathrm{a}$ & $86 \mathrm{a}$ & $163 \mathrm{a}$ \\
\hline \multicolumn{5}{|c|}{ Shearing Treatment 4} \\
\hline 1 & 57 & $2.7 \mathrm{e}$ & $95 \mathrm{c}$ & $62 \mathrm{~d}$ \\
\hline 2 & 60 & $2.8 \mathrm{de}$ & $78 \mathrm{bc}$ & $73 \mathrm{bcd}$ \\
\hline 3 & 59 & $3.2 \mathrm{c}$ & $60 \mathrm{ab}$ & $93 \mathrm{abc}$ \\
\hline 4 & 59 & $3.4 \mathrm{~b}$ & $56 \mathrm{ab}$ & $114 \mathrm{a}$ \\
\hline 5 & 57 & $2.9 \mathrm{~d}$ & $72 \mathrm{bc}$ & $68 \mathrm{~cd}$ \\
\hline 6 & 58 & $3.2 \mathrm{c}$ & $64 \mathrm{ab}$ & $99 \mathrm{ab}$ \\
\hline 7 & 58 & $3.4 \mathrm{~b}$ & $58 \mathrm{ab}$ & $117 \mathrm{a}$ \\
\hline 8 & 60 & $3.2 \mathrm{c}$ & $70 \mathrm{~b}$ & $101 \mathrm{ab}$ \\
\hline 9 & 59 & $3.7 \mathrm{a}$ & $37 \mathrm{a}$ & $118 \mathrm{a}$ \\
\hline
\end{tabular}

${ }^{1}$ The total in 2005, 2006, 2007, and 2008 is the number of trees harvested; the total for 2009 is the number of trees still on the site in late 2009; totals for each treatment are the number of trees harvested in 2005 through 2008 plus the trees still on the site in late 2009. ${ }^{2}$ Percentage of trees that were USDA Premium or No. $1 .{ }^{3}$ Within a column, least squares means followed by the same letter are not significantly different based on the Tukey-Kramer test $(p \leq 0.05)$. ${ }^{4}$ The 'year $\times$ shearing treatment' interaction was not significant.

Table 3. Height and fresh weight of 185 Fraser fir Christmas trees sheared with various leader lengths.

\begin{tabular}{cccc}
\hline Year or Treatment & No. Trees $^{\mathbf{1}}$ & Height (m) & Fresh Wt (kg) \\
\hline \multicolumn{4}{c}{ Year } \\
\hline 2008 & 106 & $3.6 \mathrm{~b}^{2}$ & $60 \mathrm{~b}$ \\
2009 & 79 & $4.0 \mathrm{a}$ & $82 \mathrm{a}$ \\
\hline \multicolumn{4}{c}{ Shearing Treatment $^{2}$} \\
2 & 14 & $3.1 \mathrm{f}$ & $60 \mathrm{c}$ \\
3 & 11 & $3.4 \mathrm{ef}$ & $60 \mathrm{c}$ \\
4 & 23 & $3.8 \mathrm{~d}$ & $72 \mathrm{abc}$ \\
5 & 30 & $4.0 \mathrm{bc}$ & $76 \mathrm{ab}$ \\
6 & 15 & $3.4 \mathrm{e}$ & $64 \mathrm{bc}$ \\
7 & 21 & $3.8 \mathrm{~cd}$ & $72 \mathrm{abc}$ \\
8 & 28 & $4.1 \mathrm{~b}$ & $77 \mathrm{ab}$ \\
9 & 20 & $3.8 \mathrm{~cd}$ & $73 \mathrm{abc}$ \\
\hline
\end{tabular}

${ }^{1}$ The number of trees weighed in 2008 was less than the number harvested because several identification tags were lost during harvest; the number of trees weighed in 2009 was a subset of all the trees still on the site late in 2009. ${ }^{2}$ Within a column, least squares means followed by the same letter are not significantly different based on the Tukey-Kramer test $(p \leq 0.05)$; the 'year $\times$ shearing treatment' interaction was not significant.

Analysis of variance for height, market value, and fresh weight was carried out with the GLM Procedure in SAS (SAS Institute, Inc., Cary, NC, USA) [10]. The sources 'year' and 'shearing treatment' were included as fixed effects. The 'year $\times$ shearing treatment' interaction was not significant, so the analysis was rerun without the interaction term. Least squares means were compared with a Tukey-Kramer test $(p \leq 0.05)$. Tree grade, a binomial variable (values $=1$ and 2 ), was analyzed with the GLIMMIX procedure in SAS using a logistic link function. Least squares means were compared with a Tukey-Kramer test $(p \leq 0.05)$. 


\section{Results}

Commercial height in 2005 averaged $2.3 \mathrm{~m}$, and increased steadily to $3.9 \mathrm{~m}$ in 2009 (Table 2). Similarly, market value increased each year, but the gain from 2007 to 2008, was large compared to any other year-to-year difference (Table 2). Tree grade also improved gradually during the rotation, i.e., 55\% of trees harvested in 2005 were USDA Premium or No. 1 grade compared to 86\% in 2009.

Shearing with different leader lengths resulted in significant differences in commercial height, tree grade, and wholesale value (Table 2). Long leaders (41 and $46 \mathrm{~cm}$; Treatments 4, 7, and 9) yielded trees with an average height of $3.5 \mathrm{~m}$, whereas trees with short leaders $(25$ and $30 \mathrm{~cm}$; Treatments 1, 2, and 5) averaged $2.8 \mathrm{~m}$ (Table 2).

Leader length also affected tree grade (Table 2); in general, long leaders resulted in a lower average grade compared to short leaders. In Treatment 1 (25-cm leaders), 95\% of the trees were USDA Premium or No. 1 grade compared to $37 \%$ for Treatment 9 (46-cm leaders). Corresponding figures for $30-\mathrm{cm}$ (Treatments 2 and 5), 36-cm (Treatments 3 and 6), and 41-cm leaders (Treatments 4 and 7) were 75, 62, and $57 \%$, respectively (Table 2 ).

The height at which leader pruning began had negligible effect on average height among treatments. Treatments 2 and 5 (30-cm leaders), where leader pruning began at $0.9 \mathrm{~m}$ and $1.5 \mathrm{~m}$, respectively, averaged 2.8 to $2.9 \mathrm{~m}$ (Table 2). In a similar comparison, Treatments 4 and 7 (41-cm leaders) yielded trees with an average height of $3.4 \mathrm{~m}$ after 9 years (Table 2). The height at which leader pruning began also had no effect on USDA grade, market value, or fresh weight (Tables 2 and 3).

Leader length significantly affected wholesale value (Table 2). Average wholesale value of trees sheared with 41-46-cm leaders (Treatments 4, 7, and 9) was \$116 (US) compared to \$68 (US) for trees sheared with 25-30-cm leaders (Treatments 1, 2, and 5) (Table 3). Trees with 36-cm leaders (Treatments 3 and 6) had an average wholesale value of $\$ 96$ (US).

The average fresh weight of trees weighed in 2009 was 37\% heavier than trees weighed in 2008 (Table 3). Just as with height and market value, fresh weight also varied significantly among shearing treatments (Table 3). Long leaders (41 and $46 \mathrm{~cm}$; Treatments 4, 7, and 9) yielded trees with average fresh weight $27 \%$ greater than trees with short leaders (25 and $30 \mathrm{~cm}$; Treatments 1, 2, and 4) (Table 3).

\section{Discussion}

Sheared leader length influenced height, fresh weight, USDA grade, and market value of Fraser fir Christmas trees (Tables 2 and 3). Increasing height was associated with a lower average USDA grade (Table 2). There was a trade-off between larger trees of lower average grade versus smaller trees of higher average grade. Average wholesale value of trees sheared with long leaders (36 to 46-cm; Treatments 3, 4, 6, 7, and 9) was about $24 \%$ greater than that of trees with short leaders $(25$ to $30 \mathrm{~cm}$; Treatments 1, 2, and 5; Table 2). Thus, the average gain in height compensated for the lower grade owing to increasing market value as height increased, especially for trees $\geq 3.0 \mathrm{~m}$.

The manner in which trees were removed over time differed from usual cultural practices where growers remove about $25 \%, 50 \%$, and $25 \%$ of the crop in the first, second, and third year of harvest, respectively. In that system, the biggest and fastest growing trees are removed first, and the slower growing trees are harvested in years 2 and 3 as they reach marketable size. That harvesting method also yields consistent USDA grade over time. In this study, the gradual improvement in USDA grade over time in most treatments (Table 2), especially those with longer leaders, indicated that trees of lower grade tended to be removed first. For example, if the choice were between removing a tree of high grade vs. one of lower quality, the tree of lower grade probably was cut first. The exception was in trees sheared with short leaders $(25$ to $30 \mathrm{~cm}$ ) where about 95\% of the trees were USDA Premium or No. 1 throughout the experiment (Table 2). The difference in thinning methods between this study and operational practice, however, did not affect overall conclusions with respect to treatment effects on the growth and quality of individual trees.

In this study, shearing treatments were randomly assigned to trees without any consideration for attributes such as bud density and branch density. For example, in Treatment 9 (long leaders), 
some trees had low lateral bud density, whereas others had medium or high bud density. This method would be expected to yield trees of lower average density and USDA grade compared to treatments applied similarly with short leaders. In practice, however, a Christmas tree grower would use long leaders only on a small percentage of trees with rapid growth and high lateral bud density, so those trees would be expected to have a better average USDA grade compared to a randomly selected group of trees pruned with long leaders. As a further safeguard to quality, if a tree declines in vigor or bud density during the rotation, the leader length can be reduced to increase crown density.

The initial hypothesis was that short leaders $(25-30 \mathrm{~cm})$ would yield trees shorter, denser and heavier than trees with long leaders $(36-46 \mathrm{~cm})$. Ultimately, however, trees sheared with long leaders were taller, had greater trunk diameter (data not shown), and were heavier than trees with short leaders (Tables 2 and 3). Biomass production by sheared Fraser fir Christmas trees is about 37\% to $53 \%$ less, depending on the timing of shearing, than that of non-sheared trees of the same age and provenance [3,4]. Balsam fir (Abies balsamea L.) and Fraser fir produce heavier bud density toward the upper (distal) end of the leader $[5,11,12]$. There is considerable tree-to-tree variability in bud density on the leader, especially on the lower (proximal) end near the first whorl of branches [12]. Fraser fir Christmas trees usually produce leaders 50 to $75 \mathrm{~cm}$ in length, sometimes longer. More than half of the leader frequently is removed by shearing, along with all buds on the distal end. Consequently, bud density on the lower half of the leader often determines tree density and subsequent leader growth. Buds are a sink for nutrients and water, and the growth potential of a leader is related to its length and diameter as well as the number of buds present $[12,13]$. Therefore, greater biomass production by trees with longer leaders likely resulted from (1) more residual buds still on the leader after shearing; and (2) greater sink strength as a result of higher bud numbers.

Fraser fir exhibits strong heritability for traits that influence Christmas tree quality, e.g., height growth, crown density, bud density [6]. In commercial plantations of Fraser fir, exceptional individuals often appear one to two years older than other trees after an eight-year rotation. Those trees grow fast and have high crown density, but they also require less shearing, and can be left with a longer residual leader each year. Thus, trees with high growth potential can realize more of that growth potential by receiving less intense shearing. This, in turn, yields larger and more valuable trees during a rotation of fixed length.

Fraser fir Christmas tree plantations traditionally are sheared to a certain target leader length depending on stand age. Uniform shearing reduces tree-to-tree variability in height and crown width. The same population, if not sheared, would display greater variation in height and crown density among trees. If a grower has a market for some tall trees, he/she can take advantage of the inherent variation among trees by using two shearing systems. In one system, more traditional leader lengths of 30 to $36 \mathrm{~cm}$ can be used on the bulk of the crop (95-99\% of trees), and a second system using leader lengths of 41 to $46 \mathrm{~cm}$ can be applied to trees with good vigor and high bud density ( $1-5 \%$ of crop) to produce a cohort with greater commercial height and market value by the end of the rotation. Both systems are compatible with the standard practice of harvesting a plantation over a period of three to four years. A similar approach has been suggested for noble fir (Abies procera Rehd.) in the Pacific Northwest, USA [14].

Shearing techniques that employ long leaders should be applied only to the trees of highest vigor and density. The best trees normally are evident by the time they reach 1 to $1.3 \mathrm{~m}$ in height. A common mistake with Fraser fir is to begin shearing when trees are too small. Unless a tree needs corrective pruning, there is little justification to prune the leader before the terminal bud cluster reaches a height of $1 \mathrm{~m}$. If a tree is targeted to be $\geq 3 \mathrm{~m}$ in height, leader pruning can be delayed until it is $1.5 \mathrm{~m}$ tall. In this experiment, the height at which leader pruning commenced $(0.9 \mathrm{vs} .1 .5 \mathrm{~m})$ had no effect on the average tree height, grade, fresh weight, and market value after nine years (Tables 2 and 3). Regardless of height when leader pruning begins, side shearing is needed as early as $1 \mathrm{~m}$ in height to establish narrow crown taper. In addition, with increasing tree height, it becomes more important to maintain narrow crown taper to prevent overcrowding later in the rotation. 
Aside from the direct effects of shearing on tree growth and quality, other factors also must be considered in choosing an optimum leader length. There are risks associated with long leaders. First, bud set and growth must be good; otherwise, crown density will be too open. This means that soil fertility must be adequate. Second, long leaders increase the risk from factors such as late frost and hail storms. These events, which occur about once every decade in western North Carolina, can lead to gaps or distinct differences in crown density, which can reduce USDA grade, or make the tree a cull. Third, if long leaders are used over a period of years, changing to a short leader length might result in 'shoulders' in the upper crown. A 'shoulder' occurs when the lateral shearing line in the upper crown is curved rather than straight. Maintaining proper taper is easier with long leaders. A big change in leader length also might cause a tree to have uneven density, making it a No. 2 or cull. Finally, trees occasionally produce heavy cone crops, and the reduction in quality is more difficult to overcome in trees with long leaders.

Short leaders $(25$ to $30 \mathrm{~cm}$ ) also have potential risks. First, short leaders increase the incidence of undesirable 'horns' or off-center tops in sheared trees. A 'horn' is a branch shoot (second-order lateral) that emerges from a bud on a primary branch (first-order lateral) in the top whorl, and turns inward into the crown. Ideally, lateral shoots should grow outward. Short leaders generally have fewer residual buds, making them less dominant over upper-whorl branches that can produce horns. Trees with long leaders are less likely to produce horns. Short leaders also increase the risk of developing shoulders as trees get taller.

Even though leader length clearly influences tree growth and quality, selection of a leader length to use must be tied to the market demand for trees of various height. About two-thirds of Fraser fir Christmas trees in the American market are 1.8 to $2.4 \mathrm{~m}$ in height. Market share decreases with increasing height, perhaps comprising only $3-4 \%$ for trees $\geq 3.0 \mathrm{~m}$. A grower can produce no more tall trees than he/she can sell in the market, so the shearing regime must be tailored mostly for trees in the 1.8-2.4-m height class. Assuming good bud density on leaders and branches, the optimum leader length appears to be 30 to $41 \mathrm{~cm}$ in plantations in western North Carolina, but it can be reduced, if necessary, to increase crown density. Trees with high bud density can be sheared with $41-46-\mathrm{cm}$ leaders. However, if a tree previously groomed with long leaders decreases in vigor or bud density, its leader length can be shortened. In other regions of the United States, with different soils and climate, there might be differences in growth and budset of Fraser fir compared to North Carolina, so leader length can be adjusted accordingly to maintain the desired tree density and quality.

Integrating two shearing systems creates additional inconvenience and expense compared to standard shearing. First, a marking system is needed for 'leave trees' that is not too labor intensive or expensive, and does not interfere with annual shearing. Second, workers must handle additional equipment such as ladders and extended pruners to reach the upper whorl and leader after tree height exceeds about $2.5 \mathrm{~m}$. Third, when marking trees for harvest, the grower must be careful to maintain adequate growing space for select trees. Finally, if a grower chooses to extend a rotation beyond the customary three to four-year cutting cycle to produce larger trees, there is an opportunity cost associated with delaying the onset of the next rotation. However, the greater market value of trees in the taller size classes tends to mitigate that cost.

\section{Conclusions}

In plantations of Fraser fir Christmas trees, shearing systems that use varying leader lengths yield trees with a range in height, fresh weight, USDA grade, and market value, especially in long rotations. When treatments are randomly applied to the trees in a plantation, long leaders tend to produce taller trees with lower average grade but higher average market value, whereas short leaders yield trees shorter in stature, with higher average grade but lower average market value. Assuming good bud density on leaders and branches, and considering other factors as well, the optimum leader length for Fraser fir in western North Carolina plantations appears to be $30-41 \mathrm{~cm}$, but that length can be reduced on individual trees, if necessary, to achieve desired crown density. 
Author Contributions: E.H. designed the experiment, and participated in installation, marking trees, annual data collection, shearing, harvesting, weighing, and data analysis. In addition, he wrote this publication. B.D. and E.D. donated land and Christmas trees, maintained the plantation, provided labor for shearing, participated in annual data collection, graded trees; harvested, baled, and weighed trees; marketed the trees, provided market valuations based on their wholesale pricing system, and gave other support as needed.

Funding: This research was funded in part by the North Carolina Agricultural Research Service (NCARS), Raleigh, NC 27695-7643 and the North Carolina Christmas Tree Association, Boone, NC, 28607, USA.

Acknowledgments: Results have been discussed at several Christmas tree commodity meetings as well as the Ninth International Christmas Tree Research and Extension Conference [15]. Those presentations did not have the final data set, and included no statistical treatment of the data. The senior author extends special thanks to Earl and Betsy Deal for graciously providing meals and housing on many occasions during the life of the experiment. The authors thank John Frampton (Dept. of Forestry and Environmental Resources, N.C. State Univ.) and Consuelo Arellano (Dept. of Statistics, N.C. State Univ.) for assistance with statistical programs and interpretation.

Conflicts of Interest: The authors declare no conflict of interest.

\section{References}

1. Brown, J.H.; Heiligmann, R.B. Shearing West Virginia Balsam (Canaan) and Fraser Fir for Christmas Trees; Ohio Agricultural Research and Development Center: Wooster, OH, USA, 2002; Special Circular 188; p. 30.

2. Douglass, B.S. Noble fir shearing and fertilizer study. In Christmas Tree Lookout; Pacific Northwest Christmas Tree Assoc.: Salem, OR, USA, 1983; Volume 16, pp. 30-32, 34, 36, 38, 40.

3. Hinesley, L.E.; Derby, S.A. Shearing date affects growth and quality of Fraser fir Christmas trees. HortScience 2004, 39, 1020-1024.

4. Hinesley, L.E.; Derby, S.A. Growth of Fraser fir Christmas trees in response to annual shearing. HortScience 2004, 39, 644-1646.

5. Powell, G.R. Shoot and bud development in balsam fir: Implications for pruning of Christmas trees. For. Chron. 1982, 58, 168-172. [CrossRef]

6. Arnold, R.J.; Jett, J.B.; McKeand, S.E. Natural variation and genetic parameters in Fraser fir for growth and Christmas tree traits. Can. J. For. Res. 1994, 24, 1480-1486. [CrossRef]

7. U. S. Department of Agriculture (USDA). Web Soil Survey; USDA, Natural Resources Conservation Service, Soil Survey Staff: Washington, DC, USA. Available online: https://websoilsurvey.sc.egov.usda.gov/ (accessed on 1 March 2018).

8. U. S. Department of Agriculture (USDA). 2012 Plant Hardiness Zone Map; USDA, Agricultural Research Service: Washington, DC, USA, 2012. Available online: http:/ / planthardiness.ars.usda.gov/PHZMWeb/ (accessed on 1 March 2018).

9. U. S. Department of Agriculture (USDA). United States Standards for Grades of Christmas Trees: Revised, Effective 30 October 1989; FR Doc. 89-23043; U.S. Department of Agriculture Agricultural Marketing Service: Washington, DC, USA, 1989.

10. SAS Institute, Inc. SAS OnlineDoc ${ }^{\circledR}$; Version 9; SAS Inst., Inc.: Cary, NC, USA, 2003.

11. Powell, G.R. Initiation and development of lateral buds in Abies balsamea. Can. J. For. Res. 1974, 4, 458-469. [CrossRef]

12. Powell, G.R. Initiation and development of subterminal buds in Abies balsamea. Can. J. For. Res. 1977, 7, 258-262. [CrossRef]

13. Little, C.H.A. Apical dominance in long shoots of white pine (Pinus strobus). Can. J. Bot. 1970, 48, $239-253$. [CrossRef]

14. Tillman, J. Stretching it to the limit. In Northwest Lookout; Pacific Northwest Christmas Tree Growers' Assoc.: Salem, OR, USA, 2002; Volume 35, pp. 9, 11.

15. Hinesley, E. Growth, quality, and economic value of Fraser fir sheared with varying leader lengths in North Carolina, USA. In Proceedings of the 9th International Christmas Tree Research \& Extension Conference, Washington, DC, USA, 13-18 September 2009; pp. 98-102. 